\title{
The Emergence of the Islamic Messiah Al Mahdi and his "Ideal" State
}

\author{
Vladimir Stefanov Chukov \\ University of Ruse "Angel Kanchev", Ruse, BULGARIA \\ Faculty of Business and Management, Department of Economics
}

Received: 1 November 2021 - Accepted: 25 December 2021 - Published Online: 27 December 2021

\section{Abstract}

This study aims to present the emergence of the Islamic Messiah Al Mahdi and his "ideal" state. Many modern preachers, clerics and thinkers are trying to find the signs of the appearance of the expected messiah given by Sharia tests and their interpretations by Islamic legal authorities. Thus, they create their own geopolitical versions, explaining modern political dynamics, based on their aspirations to build the ideal state formed under the light of the crescent. The dispositions of the Sharia norms are explained in a way that forms a logical-looking version of the emergence of a universal just state, led by the expected savior - Imam Mahdi. Muhammad

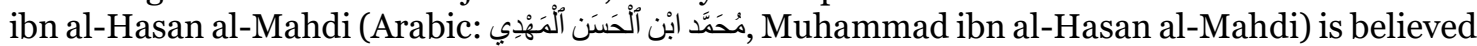
by Twelver Shia to be the Mahdi, who has two other eschatologists with Jesus (Jesus) to fulfill their mission to bring peace and justice to the world. The Shivers of Twelver believe that al-Mahdi was born on the 15th of Sha'ban in $870 \mathrm{AD} / 256 \mathrm{AH}$ and adopted the Imam at the age of almost four after the assassination of his father, Hassan al-Askari. In the early years of his Imam, he is believed to have had contact with his followers only through the Four Deputies. This period was

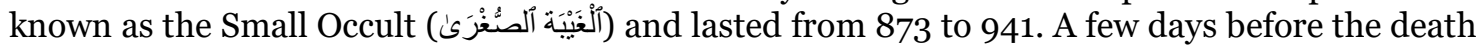
of his fourth deputy Abu al-Hasan Ali ibn Mohammed al-Samari in 941, he is believed to have sent a letter. to his followers. In this letter from Al-Samari, he announced the beginning of the

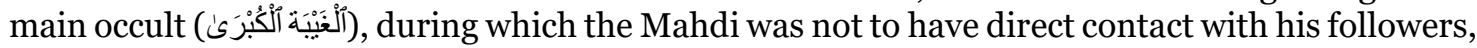
but had instructed them to follow the pious high clergy he had mentioned. some distinctive merits.

Keywords: emergence, the Islamic Messiah Al Mahdi, Israel, Evangelism, Jaafarism (Shiism).

\section{Introduction}

Many modern preachers, clerics and thinkers are trying to find the signs of the appearance of the expected messiah given by Sharia tests and their interpretations by Islamic legal authorities. Thus, they create their own geopolitical versions, explaining modern political dynamics, based on their aspirations to build the ideal state formed under the light of the crescent. The dispositions of the Sharia norms are explained in a way that forms a logical-looking version of the emergence of a universal just state, led by the expected savior - Imam Mahdi.

If politicians are relatively flexible or refrain from such explanations, taking into account the socio-economic and political realities of their time, then the Ulema are freer to do so - they have no political responsibility and are free to indicate geographical locations or dates.

(C) Authors. Terms and conditions of Creative Commons Attribution 4.0 International (CC BY 4.0) apply. Correspondence: Vladimir Stefanov Chukov, University of Ruse "Angel Kanchev", Faculty of Business and Management, Department of Economics, Ruse, BULGARIA. E-mail: vladimir chukov@abv.bg. 
associated with the appearance of the messiah, who are quickly exposed as a lie or an obvious manipulation. However, the latter has a strong enough influence for a relatively long time, both on politicians and on public opinion - it is able to reproduce enough unexpected and radical consequences.

For example, Madeleine Kasab, a researcher at the University of Leiden in the Netherlands, divides the signs of the Mahdi's appearance into well-known (already quoted in the main Sharia and interpretive medieval faqih texts) and the detailed features derived from individual Islamic preachers. The main reason for the emergence of the Messiah is the spread of injustice and corruption in various forms around the world. ${ }^{1}$ According to the author Ali alHusseini, the most characteristic of the total crisis in society are "constant blasphemy, de-Sharia lawmaking, ignoring Sharia schools, destroying religious temples, killing Muslims and clerics, the silence of scholars for good, total and evil, the spread of homosexuality, adultery, and the complete decline of morality."2 Interpretations of the appearance of the Messiah by two Sunni preachers, Sheikh Mohammed al-Arifi and Omran Hussein, are interesting. They say he will be Sunni. They explain this fact by the fact that he will appear in Mecca. Local Muslims, professing Sunni, will oblige him to accept their way of preaching Islam. They shed light on the fact that the Mahdi is a member of Ahl al-Bayt, the family of the house of the Prophet Muhammad. The two Sunnis are of the opinion that no Shiite can carry the message of universalism and is able to create a world state. According to al-Arifi, in just one night, Allah will inspire the Messiah and prepare him for his task. The preacher is of the opinion that the Mahdi will be born an ordinary man, but will suddenly become the Messiah. God will change his status in just one day3 (see Chukov, 2021).

\section{Al Mahdi}

Such reflections are intended to prepare Muslims to be constantly ready for the appearance of $\mathrm{Al}$ Mahdi Al Montazar, the expected messiah. The most important characteristic of the Messiah is that people will oblige him to accept their devotion, not impose it on them. Muslims will point to him, and he will not declare himself as such.

Among the detailed features of the appearance of the messiah are some contemporary events that are "embedded" within the dogmatic texts of medieval historical texts. One such event is the assassination of former Iraqi President Saddam Hussein. The latter is described as a "caliph",4 after whose elimination, an energetic Shiite cleric will emerge who will gain great influence in Iraq. It is about the Iraqi opposition Mokdata al Sader. The latter is recognized as the powerful figure who comes after the "caliph", whose appearance is a medium-tall, black-haired

\footnotetext{
${ }^{1}$ The Dawa Network, Abdul-Fattah Hamdash, There Is Only One Event for Mahdi to Appear, o1 October 2017. https://www.youtube.com/watch?v=ymND7DomW4U, 25.12.2020.

${ }^{2} \mathrm{Al}$ Husseini, A., Who Guaranteed Nasrallah's Advent? How Did He Meet Mahdi? Orient Net, 03.11.2014, http://www.orient-news.net/ar/news show/82399, 25.12.2020.

3 The Truth-Seeker, Alsheikh Muhammad Alarifi, The Appearance of Mahdi Series, First Part, 24.09.2014. https://www.youtube.com/watch?v=XEQa5SoDLF8, 25.12.2020.

4 Saddam Hussein is also identified as Ace Safiani. Former terrorist number one Abu Musab Az Zarqawi, who was killed by the Americans in 2006, is also a candidate for the post. He is one of the most sworn enemies of the Shiites. The reason for this statement is that the birthplace of I Zarqawi - the city of Zarqa in northern Jordan is relatively close to the valley of Wadi al Yabis, from where, according to Sharia sources, al-Safiani will appear. For more information, see: Abd Muhammad Hasan, Iqtaraba al-zuhur, Dar alMahajja al-Bayda, Beirut, 2006, pp. 125, 133, 25.12.2020 (see Chukov, 2021).
} 
man who is ravaging Iraq and causing suffering to the people of the country. Then the Mahdi appears $^{5}$ (see Chukov, 2021).

Preacher Abdul Fatah Hamdash claims that "the caliphs are fighting for the treasures of the Ka'bah." He thus explains the split in 2017 between the member states of the Gulf Cooperation Council. ${ }^{6}$ The Sunni preacher went on to say that Iraq would be besieged by Iran and Syria by the "Romans." Under the latter, he perceives a mixed group of foreigners, formed by representatives of Europe, the United States and Russia. ${ }^{7}$

There is a clear discrepancy in the interpretations of Shiite and Sunni messianic visions. By using identical terms, they give them different content. For example, if there is a consensus on Saddam Hussein that he falls into the category of al-Safiani, it is not the case with Syrian President Bashar al-Assad. For the Sunnis, he provoked the fit, civil war in Syria and also embodied the sinister As Safiyani. Along with that, he is part of the other factor involved in the battle for Sham, Syria. It is about al-Companions, friends, followers. For Shiites, this term symbolizes the black (Abbasid-Shiite) flags and are respectively carriers of a positive connotation. In contrast, Sunnis find the opposite meaning in the word. They find arguments for this thesis by claiming that the word al-ashab is composed of almost the same letters as the word "asad" (in Arabic "lion"). In this logical plane, the Sunnis are convinced that this animal symbolizes the violence and persecution of civilians. Another anti-Assad argument is the appearance of Bashar Assad. He is tall, has blue eyes and blond hair, which Sunni interpreters of messianism suggest is different from the locals ${ }^{8}$ (see Chukov, 2021).

According to the current commander of the elite Al-Quds Brigade of the Islamic Guards Corps (KIG), General Ismail Kaani, the real reason for the US invasion of Iraq in 2003 was to capture Imam Mahdi. In 2015, he noted that This happened after the US military contingent heard the calls of the Iraqis. "Oh, God, hasten the appearance of the Mahdi." The Americans realized that if he showed up, then the Shiites would defeat them. to reveal the identity of the Messiah. Kaani claims that this is why the Americans conducted long interrogations with those arrested. ${ }^{9}$

\section{The "Ideal" State}

The Arab Spring is also framed in the process of the Mahdist emergence. However, Sheikh Omran Hussein expects the real appearance of Imam Mahdi to come with the end of the

\footnotetext{
5 Lovely Land, Conversations of a Group of Sheikhs, About a Tall Man before Mahdi, Al-Sham Sufyani, 05.01.2018, https://www.youtube.com/watch?v=jDKC6bSJtdU, 25.12.2020.

${ }^{6}$ It is about the split between Saudi Arabia-the United Arab Emirates-Bahrain and Egypt, on the one hand, and Qatar, on the other. For more information see: Hennessy-Fiske, M., Arab Nations Cut Ties to Qatar, Deepening Rift in the Persian Gulf, The Gazette, 5.06.2017, https://www.thegazette.com/subject/news/nation-and-world/Arab-nations-cut-ties-to-Qatar-deepeningrift-in-Persian-gulf-20170605, 16.03.2021.

7 Abu Anas, Abdul-Fattah Hamdash, We Are at the End of Time, the Conclusive Evidence of the Appearance of Mahdi, 15.11. 2016, https://www.youtube.com/watch?v=MTCQNQQ9Ots, 25.12.2020.

8 True Promise is close, Hasan Altuhami, "The Last Sign for the Appearance of Mahdi - the Events of Syria", 15.08. 2017, https://www.youtube.com/watch?v=RfXNwapc3BY, 27.12.2020.

9 Al-Khatib, M., Musaid Suleimani Yakshifu Kaifa Bahatat America an "al Mahdi" li i'tikalihi .com / story / 867502 /\% D9, 25.12.2020
} 
Saudi regime. One is immanently related to the other, as the Saudi dynasty rules the indicated place of appearance of Imam Mahdi - Mecca. ${ }^{10}$

In the popular Shiite view, the Mahdi is a vengeful figure who will first take revenge on those Sunni Muslims who prevented Ahl al-Bayt from the ruling. Practically Sunnis and Shiites argue over whose Messiah he is. As noted, the idea exists in both denominations, but the figure is different. The Messiah takes on a different profile. The Persian Ibrahim Amini collects stories from several Shiite imams, including Ali ben Abi Talib, Hassan ben Ali, Hussein ben Ali, Ali ben Hussein, Ja'far as Sadiq, Musa al Kazam, in which he clearly rejects any is a link to the expected Messiah, outside the group of Ali ben Abi Talib's successors. According to the Iranian researcher, the latter says: "The Messiah will appear at the end of time from us. There can be no Mahdi in a nation that does not expect him." "11 The dispute is of great importance. It depends on the nature of the Messiah what his deeds and functions will be. It also means what the future ideal state he is fighting for will look like.

Classical sources suggest that Mahdi will turn humanity into a huge Islamic state. At the same time, the Messiah will be especially ruthless towards existing Islamic religious educational and pilgrimage facilities. He will destroy the mosques because they have become very luxurious and are not real places of worship. The Mahdi will kill the ulema because they have failed to establish a just and correct Islamic order. In any case, the appearance of the Mahdi will lead to a sharp and total break with existing Islamic norms. ${ }^{12}$

When the Messiah appears, prosperity and comfort will prevail in people's lives. So great will be the "abundance and grace that twenty people will share the consumption of one pomegranate". ${ }^{13}$ The nations will declare allegiance to the Mahdi and fight him in the name of God's commandments. According to Sheikh al-Arifi, the Messiah will conquer Constantinople and then head to Rome and then to all of Europe. The conquests will continue until the Dajala arrives - i.e., the false Messiah. ${ }^{14}$ Then Christ will rise, come down to earth and kill Dajjal. He will then pray in Jerusalem. But he will be behind the Mahdi, who will also pray. This is a clear indication that Israel will surely be destroyed by the Mahdi, as the joint prayer of the Messiah and Christ will not take place in occupied Jerusalem. ${ }^{15}$

An interesting point is that, in fact, Sunni predictions about the Mahdi are much more strongly injected with anti-Semitism. They, in turn, influence Shiite folk beliefs about the expected messiah. In fact, this is the difference between the judgment and the content of Sunni and Shiite messianism. The former emphasizes the destruction of Judaism as a religion, and then this will happen to its followers. Sunni Kuwaiti preacher Nabil al-Audi noted: "The Mahdi will meet with the mujahideen in Damascus. Syria will return to Muslim rule only when the Jews are eliminated. Even trees and stones will say, "Oh, Muslim! There is a Jew behind me. Come and kill him."16

10 ZeLZaLFlasten, Omran Hussein, after Foreseeing the Arab Revolutions, Foresees the Moment When Mahdi Will Appear, 22.08.2011, https://www.youtube.com/watch?v=v4SUOOI5418, 25.12.2020.

${ }^{11}$ Amini, I., Al-Imam al-Mahdi, The Just Leader of Humanity.... op. cit., https://www.al-islam.org/al-imamal-mahdi-just-leader-humanity-ayatullah-ibrahim-amini/chapter-2-pseudo-mahdis, 25.12.2020.

12 Cook, D., Studies in Muslim Apocalyptic, Darwin Press, Princeton, 2002, pp. 232-236.

13 The Truth-Seeker, Alsheikh Muhammad Alarifi, The Appearance of Mahdi Series, First Part, 24 September 2014. https://www.youtube.com/watch?v=XEQa5SoDLF8, 26.12.2020.

${ }_{14}$ Alwatan Channel, Faith Program, Mansour Al-Hassani, Nabil Al-Awadi, Promised Mahdi and the False pseudo Messiah and the Descent of Isa Jesus, Son of Mary, 16 March 2014. https://www.youtube.com/watch?v=dW1gmfs-MKk, 26.12.2020.

${ }_{15}$ Op. cit.

${ }^{16}$ Op. cit. 
Under the influence of authoritative Sunni preachers and faqihs, a modern rearrangement of priorities is reproduced in modern messianic Shiite perceptions. It is about the gradual surrender of As Safiani as the main prototype of evil, at the expense of Dajala, who is practically absent in traditional Shiite scriptures, although nowadays the figure is gaining more and more popularity in modern Shiite apocalyptic materials. In medieval Shiite texts, the figure of Mahdi is much more closely associated with his opponent, As Safiani. However, modern Shiite radicals are already shifting their focus to Dajala. In fact, stories about him become tools for demonizing the West as a whole, which is routinely portrayed as the incarnation of the Antichrist. In addition, Dajala himself came very close to the notion of the Jews. In fact, the development of such views has become the basis of strong anti-Israel attacks. Only years ago, this strong antiSemitism and the approach to the destruction of the state of Israel, respectively, did not exist. Historically, it has not been in the interest of the Shiite religious leadership or al-Hauz al-Ilmiya for the Shiite religious-academic institution to promote apocalyptic expectations (see Chukov, 2021).

In the recent past, religious authorities have tried to govern "popular” Mahdism by focusing and directing messianic expectations to the more distant future rather than the immediate one. A strong and influential religious leadership could achieve this, as traditionally the return of Mahdi has never been associated with any real dates. Speculation about the Mahdi's return, when it arose, quickly shifted from al-Hauz al-Ilmiya, the Shiite religious-academic institution, to more pragmatic issues, including personal spiritual renewal or the betterment of society. However, when, to some extent, the authority of Shiite clerics eroded, popular messianic longings began to reappear. This happened at the beginning of the Baha'i movement in the 1940s.

We are currently witnessing a strong renaissance of apocalyptic beliefs in the Shiite world. The main focus is the state of Israel, not the followers of Judaism. Messianism began to "slip" out of the control of religious institutions and became a lever of influence for preachers who were not directly dependent on the state. Logically, the latter often interpret current events through the prism of socially formed populist messianism. In this way, processes known to some extent in Sunnism and Evangelism take place in Ja'farite messianism. The lowlands do not recognize the views offered by state institutions and create their own, but much more radical and elementary scenarios. These changes have important implications for Shiite social and political life. Gradually, Imamate messianism transformed from anti-Semitic to anti-Israel. The threat to the universal, social and just state of Mahdi is not the Jews as such, but their statist subject - the state of Israel. The latter is part of Dajala, the sum of all external hostile factors. It is even his vanguard, as it is located in the Middle East and in this capacity is the bearer of the direct threat against the Mahdist state.

One of the most active propagandists of the Mahdist idea in the world is the former Iranian President Mahmoud Ahmadinejad (2005-2013). His supporters go so far as to claim that he is the world representative of Mahdi. He left letters to the Messiah in the mosque in the holy city of Jamrakan, ordered the streets of Tehran to be cleared quickly because of the impending appearance of the Messiah. According to the former president of the Islamic Republic, ISIL appeared to stop the appearance of Mahdi. The terrorist organization adopted this name (you give it as an abbreviation in Arabic) because it sounded close to that of the Shiites (neck in Arabic). Ahmadinejad notes: "My government has followed in the footsteps of Imam Mahdi's world power." ${ }^{17}$ During his first term, the former president predicted that "the expected Messiah will appear in four years."

Mahmoud Ahmadinejad has repeatedly stated: "The Mahdi is the one who runs the country." It even goes so far as to claim that "Hugo Chavez is one of the supporters of Imam Mahdi." He also began to talk about his meeting with the Messiah. Sheikh Al Misbah al Yazdi, a

${ }_{17}$ Fadil, S., Hal Takhala al Imam al Mahdi an Ahmadi Nadjad, Jamahir Hezbollah? 12/27/2020. 
Shiite jurist-theologian, whom Ahmadinejad takes as his margin, a source of religious norms, i.e., of fatwas, notes: "We live in a time of the reappearance of Imam Mahdi, who elected Ahmadinejad president." The same was declared by one of the most famous ulema in Kom, the Great Ayatollah Mohammed Bahjat al-Fomni (1915-2009). The latter added in this connection: "The elderly of our time will witness the appearance of Imam Mahdi”, without specifying the exact date. ${ }^{18}$

Ahmadinejad's followers formed the Khujaji movement, which promoted the Mahdi's global government. They are making a documentary called The Emergence. It discusses the role of Ahmadinejad in preparing the Middle East for the coming of the Messiah. Books promoting the occult of the Messiah are being distributed in the book market in Lebanon, Iraq and Iran. A whole section of research is being created, which we can figuratively call "Mahdology". Among the leading titles is Abdel Mohammed Hassan's "Approach the Appearance”, which states the exact date of the appearance of the Messiah, namely January 19, 2008. Similar "fundamental" studies are "The Appearance of Imam Mahdi, Peace be upon him, in 2015 according to the Qur'anic Jaber al-Balushi's "Prediction", Faris Faqih's "Now You Are in the Age of Emergence”, Majid al-Mahdi's "War of the Americans against the Mahdi, Peace be upon him", Shadi Faqih's "Ahmadinejad and the Future World Revolution", "Prepare, the appearance is recent" by Hussein al-Hijazi and "The Emergence" by Abdul Mohammed Hassan of Iraq.

It is as if all these authors have succeeded in making serious contributions to the scientific field, the author of which in Iran, as we have already noted, is considered to be Ali Shariati, namely the sociology of religion. They develop a special imaginary case - a sociopsychological concept of waiting. It is directly related to the Mahdi doctrine and can be considered in three planes:

- Cognitive impact. This means forming a culture and a mass consciousness of waiting, in order for society to take the right position towards Mahdism and the emergence of the Messiah, respectively;

- The emotional impact. This means building mental resilience and fighting against the factors that erode the perseverance in the faith of the promises of the Messiah;

- The behavioral effect. This means the development and implementation of Sharia law governing Islamic daily behavior at the level of the individual, group and society. 19

Undoubtedly, the merits of Mahmoud Ahmedinejad are enormous for the growth of Mahdology. At the same time, it is unclear whether this is his true faith in the Mahdist idea or whether it is a matter of well-calculated and well-constructed political ambitions. His constant statements about the appearance of the Mahdi turned against him the influential stratum of senior Shiite clerics. The latter, including Spiritual Leader Ayatollah Ali Khamenei, are beginning to suspect that Ahmedinejad is trying to attack the institutionalized post-Islamic political system of Wilat al-Faqih, the guardianship of the theologian. According to its principles, the Spiritual Leader leads the state of substitution, ie. in the absence of the expected Messiah. When the latter appears, the Spiritual Leader must cede power to him (see Chukov, 2021).

Mahmoud Ahmadinejad has the greatest credit for separating anti-Semitism from anti-Israelism as the basis of Mahdist doctrine. He constantly emphasizes the immanence of the

${ }_{18}$ Biography of the Great Ayatollah Sirat Ayatollah al-Azma Ash Sheikh Mohammed Taki Bahjet / Kadasa Sirahu /, Sheikh Mohammed Taki Bahyat, May His Life Be Enlightened, Wikalat al Anba Brata, 15.05.2009, http://burathanews.com/arabic/reports/66010, 1.01.2021.

${ }^{19}$ As Sade, M., Dirasa an taukit zahur al imam al mahdi al montazar, Study of the time of the appearance of the expected messiah, Markaz at dirasat al mokhasasa lil imam al mahdi, https://www.mmahdi.com/main/articles-1018, 12/29/2020. 
removal of the state of Israel from the face of the earth. Such aggressive statements are usually made by Iranian leaders on the day of Jerusalem, the last Friday of Ramadan. For example, in a speech at the University of Tehran on 8 August 2012, the former president stated that "Israel is a tumor education that will soon be eliminated." ${ }^{\circ 0}$ In fact, Ahmadinejad has repeatedly stated that the erasure of Israel is one of the hallmarks of the emergence of the Messiah. ${ }^{21}$

Similar threatening speeches were made on the Day of Jerusalem by the Spiritual Leader of the Islamic Republic, who even set a date for the destruction of the Jewish state. In his introduction, Ayatollah Ali Khamenei always includes the following temporal explanation: “... in forty days Israel will be destroyed. "On 11 March 2021, Iranian Defense Minister Amir Khatami declared that if Israel took a preemptive strike against Iran, the Islamic Republic would wipe out Tel Aviv and Haifa." Such a threat is permanent, especially against the background of the unprecedented attack at the same time by ten drones shot down by Yemeni Hutus rebels against various targets in Saudi Arabia. In this case, however, the Minister of Defense says that this time things are serious, as the orders were given personally by the Spiritual Leader Ali Khamenei. ${ }^{22}$

Tehran's anti-Israelism has grown especially since the conclusion in late 2020 of the Abrahamic treaties between the Jewish state and four Arab states, namely the United Arab Emirates (UAE), Bahrain, Morocco and Sudan. Such a move is seen as a siege of the Islamic Revolution in its battle against Israel. In this regard, Tehran is particularly sensitive to the expansion of the network of Israeli embassies in Arab and Islamic countries. For example, the statement of the assistant to the Speaker of the Iranian Parliament Hussein Abdel Lahan that "the UAE and Bahrain will have internal problems due to the establishment of a peace treaty with Israel" is a direct threat to interference in their internal affairs. ${ }^{23}$ Especially in the second country, there is a huge Shiite community (it is even a majority in relation to the ruling Sunni minority) that is often manipulated by mullahs in Iran.

Pope Francis' visit to Iraq in March 2021 revealed a similar attitude towards neighboring Iraq. It has acquired a historical character, as it is the first in this Arab country. The fact that more than 10,000 media outlets around the world have covered it speaks volumes about its unprecedented nature. On 6 March 2021, the head of the Roman Catholic Church led the common prayer in the birthplace of the prophet Abraham, the historic city of Ur.

Even more interesting was the meeting with Iraq's top Shiite Marj'a, Grand Ayatollah Ali al-Sistani. The statements made by the office of the Iraqi cleric and the Vatican were in line with the spirit of understanding, tolerance in rejecting war, terrorism and violence. Apparently, this corresponded perfectly to the authority of the two spiritual leaders. Beneath the surface, however, there were certain discrepancies between the two interlocutors, whose conversation lasted about forty minutes. This is clear from comments in Tehran and pro-Iranian Middle Eastern publications. Differences in thinking have also emerged between al-Sistani and Iraqi Prime Minister Mustafa Kazimi. The latter declared on 6 March a "National Day for Tolerance and Coexistence”. Najaf, home to Iraq's most authoritative religious school and Ali al-Sistani have not commented on the act.

${ }^{20}$ Nadzhad yuakadu anna izrail „uoram sartani sayazilu“ (Najad confirms that Israel is a tumor education "that will be eliminated"), AFP, 18.08.2012, https://www.france24.com/ar/20120818-\%D9\%, 30.12.2020. ${ }_{21}$ Abdel Hamid, A., Ama karib satushhadun zual izrail min uzhud (You will soon witness the demise of Israel), Hess Press, 13.04.2009, https://www.hespress.com/\%D8\%, 30.12.2020.

22 Iran Piles on Aggression, Emboldened by US-Saudi-Israeli Restraint, Debka, https://www.debka.com/iran-piles-on-aggression-emboldened-by-us-saudi-israel-restraint/, 10.03.2021.

23 Tawakaa irani bi mashakil dakhilia fi daulatein arabian bi sabab at tatbia (Iran's expectation of internal problems of two Arab states because of peace treaties with Israel), Arab 21, https://arabi21.com/story/1342472/\%D8\%AA\%Dq, 10.03.2021. 
Iraqi political circles shared aloud what the Iraqi prime minister had set as a political plan following the Holy Father's visit. The Iran-Iraq-Saudi Arabia race has always defined the profile of the leadership status quo in an important region such as the Persian Gulf. It is not just about the huge oil deposits, but also about the religious significance in the Islamic (Sunni and Shiite) world. After the elimination of dictator Saddam Hussein, the real Iraq fell into weightlessness. The competition has shifted between Shiite Tehran and Sunni Saudi Arabia. Following Pope Francis' visit, the request to rehabilitate Iraq as a regional power is more than obvious. A professor at Baghdad University said that if external and international factors helped, Iraq could regain its regional role in order to stabilize the region. He emphasized the fact that Pope Francis would not be able to make such a visit, either in Iran or in Saudi Arabia. He presents them as the poles of a religious, internal confessional dispute, as opposed to a moderate and tolerant Iraq.

Tehran was greatly irritated by the thesis, which is increasingly prevalent in the Arab media and political space. It is about the claim that through the Francis-as-Sistani meeting, the West has chosen Najaf's moderate school as a legitimate interlocutor and partner in the dialogue with the Shiites. Moreover, Najaf's moderate religious (and political, respectively) ideas are legitimate for Shiites, not those proposed by Kom. Interestingly, the "relevant" circles in the Islamic Republic noted that "similar speculations" behind attacks on Iran were expected.

The course of the preparations and the very realization of Pope Francis' visit to Iraq speaks of a corresponding reaction in Iran as well. It is likely that Grand Ayatollah Ali al-Sistani, who in 2004 issued a single fatwa for Iraqis to vote for the first time in a US presence in Iraq (while other religious leaders called for a boycott), made a compromise. Rather, he was subjected to strong Iranian pressure to avoid outright communist results from the Holy Father's visit (see Chukov, 2019).

Ali as Sistani was born in 1930 in Mashhad, Iran. He spent his childhood in the provinces of Sistan and Baluchistan, where his family came from and which is on the Pakistani border. Interestingly, in this administrative unit, the Sistans are a minority who speak Persian and profess Shiite Islam. The Baluchis are the majority and have their own language, but they are Sunnis. This to some extent affects the family of the future Grand Ayatollah. His father, Mohammed Bakr al-Sistani, is also a Shiite cleric, with his own religious school. The latter claims to be of the descent of the third Ja'afarite Imam Hussein ben Ali. The family lives in a specific religious environment. They are a minority in a province which, by its status, is also a minority (see Chukov, 2021).

In 1951, Ali al-Sistani came to study at the school in Najaf and remained there. Only 30 years old, he became a mujtahid, which is a higher legal dogmatic title. Interestingly, in 1993, he, an Iranian, was chosen as the highest source of religious rule-making and Grand Ayatollah of the Shiite majority in Iraq by former dictator Saddam Hussein. This was at the expense of the incredibly popular Iraqi at the time, Ayatollah Mohammad Sadiq al-Sadr, the uncle of the current leading Iraqi politician and cleric, Moqtada al-Sadr.

The preliminary program of Pope Francis' visit includes the signing of a Human Brotherhood Document, modeled on the one signed two years ago between the Holy Father and Sheikh Al-Azhar, Sunni Ahmed Tayeb. At the last moment, this symbolic gesture falls away. Al Sistani's office added that this happened, but orally, not in writing.

The seven "noes" with which Ace Sistani saturated his position before the Holy Father are impressive. There are both politics and religion in them. "No" to the siege (of Palestine by Israel), "no" to violence, "no" to oppression, "no" to poverty, "no" to restrictions on religious freedom, "no" to lack of social justice, "No" to establish relations with Israel. At the end of this declaration is the outspoken anti-Israel position. It notes: "Many people in the world in many countries suffer from injustice, oppression, poverty, religious and intellectual persecution, from 
the suppression of fundamental freedoms, from a lack of social justice, especially during wars, from acts of violence, from economic siege and resettlement of many peoples in our region, especially the Palestinian people in the occupied territories" (see Chukov, 2019).

The course of the preparations and the very realization of Pope Francis' visit to Iraq speaks of a corresponding reaction in Iran as well. It is likely that Grand Ayatollah Ali al-Sistani, who in 2004 issued a single fatwa for Iraqis to vote for the first time in a US presence in Iraq (while other religious leaders called for a boycott), made a compromise. Rather, he was subjected to strong Iranian pressure to avoid outright communist results from the Holy Father's visit.

In this light, it is necessary to add that Ali al-Sistani is not a supporter of the governor theory of al-Wilayat al-Faqih al-Mutlaq, the absolute guardianship of the theologian, created as a variant of Ja'afarite "constitutionalism" by Ayatollah Ruhollah Khomeini. However, the Iraqi Iranian is a supporter of another version of the theory, namely Wilayat al-Faqih al-Hasa, especially the trusteeship of the theologian. It is far from the most radical denial of Iranian governing clerical radicalism. ${ }^{24}$

It is more than obvious that there is Iranian pressure to thwart a peace treaty between Israel and the Iraqi state. The Baghdad presidency issued a statement saying that media statements attributed to Prime Minister Mustafa al-Kazimi that a peace treaty with Israel would be signed if agreed with the Palestinians were untrue. ${ }^{25}$

At the same time, Mahmoud Ahmadinejad's 2008 meeting in New York with twelve rabbis from the Neturei Karta religious group is symptomatic. ${ }^{26}$ These are Jewish clerics from the Haredite Alliance for Israel, who deny the creation of the state of Israel before the appearance of their Messiah. ${ }^{27}$ In Iranian political and religious doctrine, "good Jews" are those who ignore the state that their fellow believers have created in the "Promised Land."

\section{Conclusion}

Along with purely utopian constructs, one can sense the ambitions to build a powerful, theocratic-authoritarian state. It outlines the basic outlines, and the specific codified laws will be the result of the benevolence of the leader. Behind the benevolent understanding of universal and social "justice" is the relentless imposition of the Islamic religion, even on followers of monotheism (see, Chukov, 2019, 2021).

However, as imaginary as the touches of the future state of Mahdi may sound, apparently in the minds of its designers there is a profile of a statist construct, which suggests knowledge of the genesis and functioning of a state-building process.

\footnotetext{
${ }^{24}$ For more information, see: Ali as Sistani gave as much as he could or as much as he was allowed, https://www.facebook.com/foreigninsider, 8.03.2021.

25 Arriya al irakiya tanfi tasrihan haula akd itifak maa al ihtilal, the Iraqi presidency denies statements about concluding a treaty with the occupation, Al Arabi 21, 9.03.2021, https://arabi21.com/story/1341402/\%D8\%A, 10.03 .2021.

${ }^{26}$ Weiss, Y.D., The Orthodox Jewish Response to the Criticism of the Iranian President, Neturei Karta International, 28.10.2005, https://www.nkusa.org/activities/Statements/2005Oct28Iran.cfm, 30.12.2020.

${ }^{27}$ Ahmed Najad Yaltaki Khakhamat Yahudan Juaridun Kiam Israel, Ahmedinajed meets with rabbis who oppose the existence of Israel, Al Jazeera, 25.09.2008, https://www.aljazeera.net/news/international/2008/9/26/\%D8\%, 30.12.2020.
} 


\section{Acknowledgements}

This research did not receive any specific grant from funding agencies in the public commercial, or not-for-profit sectors.

The author declares no competing interests.

\section{References}

Chukov, V. (2019). The clash between Christian and Islamic religion - The State of Israel. https://doi.org/10.32591/coas.e-conf.04.07083c. In T. V. Petkova \& V. S. Chukov (Eds.) (2019). 4th International e-Conference on Studies in Humanities and Social Sciences: Conference Proceedings. Belgrade: Center for Open Access in Science. https://doi.org/10.32591/coas.e-conf.04

Chukov, V. (2021). Israel between Evangelism and Jaafarism (Shiism). [Чуков, В. Израел между евангелизма и джаафаризма. Издателство „Изток-Запад“. София. България.]. ISBN 978619-01-0856-6. Publishing House “East-West”. Sofia. Bulgaria. 